\title{
Relationship between Legible Handwriting and Level of Success of Third Grade Students in Written Expression'
}

\author{
Seher Bayat ${ }^{1}$, Hasan Küçükayar ${ }^{2}$ \\ ${ }^{1}$ Faculty of Education, Department of Primary Education, University of Ordu, Turkey \\ ${ }^{2}$ Aşağıboynuyoğun Primary School, Giresun, Turkey \\ Correspondence: Seher Bayat, Faculty of Education, Department of Primary Education, University of Ordu, Ordu, \\ Turkey.
}

Received: July 5, 2016 Accepted: July 22, 2016 Online Published: August 1, 2016

doi:10.11114/jets.v4i10.1717

URL: http://dx.doi.org/10.11114/jets.v4i10.1717

\begin{abstract}
This study aims to identify third-grade students' performance levels for written expression and handwriting and to find the relationship between these performances. The study is based on relational screening model. It is carried out with 110 third grade students. Students' levels of success in handwriting and in written expression are evaluated with observation forms developed by researchers. The results of the study reveal that third grade students' success in handwriting is good, while their success in written expression is moderate. The relationship between their success level of handwriting and that of written expression is found to be moderate as well.
\end{abstract}

Keywords: handwriting, legibility, writing expression, cursive, writing skills

\section{Introduction}

Students can express their knowledge, thoughts and feelings through writing skills. Writing is an entry level cognitive skill and it has an important place in academic success. In addition to academic life, it is necessary to have effective writing skills for business and daily life as well. The main purpose of teaching writing skills is to provide students with legible, practical and accurate (in line with spelling and punctuation rules) handwriting skill in addition to acquisition of necessary skills to express their feelings, thoughts and impressions in written form.

Before 2005, basic vertical letters were used in teaching reading and writing; and reading and writing were taught by the sentence method in Turkey. As of 2005, due to the fact that Turkish is an agglutinative language, reading and writing started to be taught with Sound Based Sentence method. By this method, it was aimed to enable the students to rapidly pass on to sound, from sound to syllables, from syllables to word, and from word to sentence and it was thought that learning reading and writing would be easier. For example, a rapid transition to the word "hand" (el) with the sounds "e" and "l" and to the sentence "Ela and Lale are hand in hand" (Ela ile Lale ele ele) with the sound "a" given thereafter was provided. Besides the sound based sentence method, teaching of cursive italic handwriting to the students was taken as a basis in the education program that was introduced in 2005 in Turkey. In Turkish Language Teaching Program (2006) the reasons for adopting slant cursive handwriting were summarized as following: "Cursive slant handwriting is aesthetic, its being continuous provides fluency in thinking, as it is suitable for kids' anatomy, it enables fluent, practical and aesthetic writing". It is possible to say that there are different views in literature with regard to cursive handwriting. It can be possible to summarize the views for and against cursive handwriting under the following sections:

\subsection{Fluency in Thinking- written Expression and Reading}

Based on studies which claim that continuous movements support fluency in thinking (Spencer et al., 2003; Giedd et al., 2001; Giedd et al., 1996) we can consider that cursive handwriting must be taught in the first years of the school as it is done so in our current education system (Bo et al., 2014). Cursive handwriting reinforces brain development. During cursive handwriting, kids make use of small muscles in their hands; they concentrate and think about how to write in order to make it legible. This, in the end, supports development of thinking skills which are necessary for reading and

\footnotetext{
${ }^{1}$ This study is a further developed form of the study presented in the 1st International Scientific Researches Conference Humanity and Social Sciences Symposium held on 19-22 May 2016 as an oral declaration.
} 
writing (Klemm, 2013). In literature (New American Cursive Penmanship Program, 2009; Owens, 2009; Troyer, 2005), it is possible to come across such views that there is a relationship between cursive writing and fluent reading and it supports fluency in reading (cited in Blazer, 2010). This is also stated among the reasons for transition to slant cursive handwriting in Turkish Language Teaching Program (MEB, 2006).

In contrast to that, in literature (Burns, 1968; Kulh \& Dewitz, 1994; Tinker, 1955) it is also emphasized by others (Burns, 1968; Kulh \& Dewitz, 1994; Tinker, 1955) that cursive handwriting causes difficulties in reading as manuscript is extensively used in the media such as books and journals etc. In his experimental study on reading comprehension of $4^{\text {th }}$ grade students, Tosunoğlu (2010) finds out that level of reading comprehension decreases when a different writing style is used other than the one used in writing activities and in reading texts. But in literature, there are also several studies (Otto \& Rarick, 1969; Duvall, 1985; Karlsdottir, 1996) concluding that use of either manuscript or cursive handwriting does not make any meaningful difference in reading skills (cited in Schwellnus et al., 2012)

\subsection{Difficulty/Easiness to Learn}

In Turkish Language Teaching program, it is observed that, students, at the beginning, draw straight and circular lines. This makes it easier for them to pass to cursive slant writing (MEB 2006). According to Mosse (1982), writing mistakes over small letters (1, I, 1 etc.) which resemble each other both physically and in terms of spelling, disappear with handwriting. According to Blumenfeld (1978) kids do not confuse letters in handwriting.

However, Bo et al., (2014), in a study on children between 5-12 ages, concludes that children can write manuscript more easily and legibly compared to cursive letters. According to Faris (1997), kids at age 3 draw simple straight lines, vertical and horizontal lines and circles. As a result of these early experiences, at age 6 or 7 they write vertical and horizontal lines more easily compared to cursive slant writing which require complex connections, because horizontal lines, which involve movement in left -right direction, and vertical lines, which involve top/bottom movements are all based on already acquired motor skills. Graham (1992) points out that hand needs to change its movement more when writing slant letters. He indicates that hand movements, which are required to write slant letters by going over existing lines with more pen movement, normally take place at the later stages of child's development. In addition to that, Karlsdottir (1996) finds out that for $75 \%$ of letters, manuscript and cursive letter shapes are of comparable difficulty.

\subsection{Writing Speed}

One of the justifications for teaching handwriting is that it enables writing fast as words are written without any interruption. Slant cursive writing is continuous and fast. In writing manuscript, it is necessary to stop at the end of each letter. That's why, writing process is often interrupted and slowed down (Güneş, 2007) Given the level of child's development at early ages, crossed lines may cause difficulties in writing (Schwellnus et al.,2012). The beginning and ending points of the letters are different in cursive and manuscript writing. In cursive handwriting, letters end in one specific point while for manuscript letters, there are eight different points where writing ends. These advantages of cursive handwriting enable easier learning and usage of the cursive handwriting alphabet as well as fast writing (Başaran \&Karatay, 2005). However, in literature comparing writing speed of students according to their writing styles, it is also possible to encounter such conclusions claiming that that cursive slant handwriting is not faster (Bayat, 2016a; Graham et al., 1998; Jackson, 1970; Trap- Porter, et al., 1984).

In sum, based on current studies (Schwellnus et al. 2012) it is difficult to say which style of writing (cursive or manuscript) is more beneficial for the children. Morin, Lavoie and Montésinos-Gelet (2012) conclude that three different styles of writing (manuscript/cursive, manuscript, and cursive) have different effects (speed, quality, word production, and text production) over writing skills. In the past, legible and stylish handwriting has been an indicator of one's level of education and his/her social status (Blazer 2010). Although today it is generally thought that cursive slant handwriting has started to lose its importance (Blazer, 2010; Armstrong, 2014; Puranik et al., 2014), teaching of handwriting skills especially in primary and secondary school programs keeps its importance despite arguments over the style of writing (cursive or manuscript) (Graham et al., 2014; Kiuhara et al. 2009; Schwellnus et al. 2012; Sharp \& Titus, 2016; Ziviani \& Watson-Will, 1998).

Whichever style of writing is chosen, in teaching writing it is targeted that student write legibly and fluently and they develop their writing skills. Whether writing is legible or not is an important factor that affects the evaluation of written expression. For example, if a text is not legible, evaluator can give a grade depending on non-accurate information. Even if the text is legible, the quality of handwriting (whether it looks nice or not) may create prejudices in evaluation of the content. In both scenarios, the grade given to the written text may not reflect the truth (Santangelo \& Graham, 2015). Taking this fact as the starting point, this study aims at evaluation of cursive slant hand writing and written expression skills of third grade students at primary school. With this purpose, answers are sought for the following questions. 
1. What is the success level of third graders in handwriting legibly?

2. What is the success level of third graders in written expression?

3. Is there any relationship between students' success levels in legible hand writing and written expression?

\section{Method}

\subsection{Method of the Study}

The study is based on relational screening model. Relational screening model "aims at determining the existence and the level of covariance between two or more variables" (Karasar, 2005: 81). Since the study intends to find out the relationship between third grade students' levels of success in written expression and level of success in stylish handwriting, it is designed in "relational screening model". With regard to data collection technique, the study is based on observation. Texts written by students are evaluated by making use of observation forms.

\subsection{Study Group}

For choosing the study group, maximum diversity method is employed among the purposeful sampling methods. The purpose here is to establish a comparatively small sample and to reflect the diversity of people that can be part of the problem studied (Yıldırım \& Şimşek, 2005). 110 third graders studying in primary schools in the city center, suburbs and villages of Giresun District are included in the sample. $61 \%$ of the students study in primary schools in the city center while $27.2 \%$ and $11.8 \%$ study in schools in suburbs and villages respectively. $47.7 \%$ of students is male and $56.3 \%$ female.

\subsection{Measurement Tools}

The study employs measurement tools for evaluation of "legible handwriting" and "written expression". In evaluation of legibility of handwriting, there are generally 5 dimensions taken into account in literature (Graham, 1982; Kaminsky \& Powers, 1981; Koenke, 1986; Rosenblum et al,, 2003; Rubin \& Henderson, 1982): shape of letters, their size, slant (slope), space between letters and writing on the line. Taking into account this criteria, Turkish Language Teaching Program and measurement tools used in the literature (Ateş \& Yıldırım, 2007; Bayat, 2016a; Bayat \& Çoşkun, 2016; Sudsawad et al, 2001), an evaluation form consisting of 10 items has been developed. Form gives the following scores: very good (5), good (4), average (3), inadequate (2) and bad (1). Views of experts (Two area experts of Classroom Teaching, one area expert of Turkish Language Teaching, one area expert of Assessment and Evaluation) have been asked about the form that have been developed. Researchers have applied the form to a group of students (63) other than the sample group in order to determine the measurement difficulties and a better-applicable form has been developed. No change has been made over the items stated in the measurement tool after this pre-application. It can be stated that such work has increased the validity of measurement tool.

In pre-application of the form, Cronbach Alpha reliability was measured at 83. After pre-application, two researchers independently gave scores to student's writings. According to data obtained through observation, the rate of coherence between evaluations made by two different observers was $81 \%$. For the main application, rate of coherence was $84 \%$. It is normally expected that rate of coherence that is used to determine inter-rater reliability is more than $70 \%$ (Tavşancıl \& Aslan, 2001: 81). Non-compatible coding has been reviewed and rated again by common decision. In conclusion, it can be stated that reliability of the scores were maintained at an acceptable level.

To make an assessment of the written expression skills, students have been asked to write a short story by using these key words: "carrot", "lie", "rabbit", "danger" and "to promise" and their writings have been evaluated by "written expression observation form" Turkish Language Teaching Program and measurement tools used in the literature (Bayat, 2014; Dağtaş, 2012; Göçer, 2010; Graham et al, 2013) have been analyzed and an evaluation form consisting of 10 items have been developed. Form gives the following scores: very good (5), good (4), average (3), inadequate (2) and bad (1). Expert views (Two area experts of Classroom Teaching, one area expert of Turkish Language Teaching, one area expert of Assessment and Evaluation) have been asked about the form that have been developed. Researchers have applied the form to a group of students (63) other than the sample group in order to determine the measurement difficulties and a more applicable form has been developed. No change has been made over the items stated in the measurement tool after this pre-application. It can be stated that such work has increased the validity of measurement tool.

In pre-application of the form, Cronbach Alpha reliability coefficient was measured at .81. According to data obtained through observation, the rate of coherence between evaluations made by two observers was $79 \%$. For the main application, rate of coherence was $82 \%$. It is normally expected that rate of coherence that is used to determine inter-rater reliability is more than 70\% (Tavşanc1l \& Aslan, 2001: 81). Non-compatible coding has been reviewed and rated again by common decision. In conclusion it can be stated that reliability of the scores were maintained at an acceptable level. 


\subsection{Data Collection and Analysis}

To make an assessment of the written expression skills, students have been asked to write a short story by using these key words: "carrot", "lie", "rabbit", "and danger" and "to promise". A process-based approach has been adopted for writing activity. The work that has been carried out under process based approach is as following:

Pre-writing: Students have been asked what the key words given to them evoke in their minds. They have been requested to create a mind map. Later, these mind maps have been shared in the class.

Drafting: In the light of key words, students have been asked to specify and write down the main subject of the story, its characters, main idea and the time of the story.

Arranging and Writing: They have been asked to write the story by making use of the mind map and draft forms they just formulated.

Re-arrangement: They have been asked to read their stories and make necessary arrangements.

Sharing: They have been asked to post their stories on the class board, to read/analyze each other's story

It took 2 classes ( 80 minutes) to apply this study in one classroom. All data was collected within 8 classes/periods.

After the stories were written, the data collected with rating of students writings were analyzed. For his purpose, standard deviation and arithmetic average calculations were made and the existence of a meaningful relationship between the legibility of handwriting and the level of success in written expression was tested with Pearson Product Movement Correlation Technique.

\section{Findings}

Data related to legible handwriting skills of third grade students are given in Table 1.

Table 1. Data related to legible handwriting skills

\begin{tabular}{lrc}
\hline Skills & s.d. & $\bar{X}$ \\
\hline 1.Shaping letters correctly, & .91 & 3.97 \\
2. Writing letters in appropriate size, & .89 & 4.19 \\
3. Writing without disrupting the slope & 1.13 & 3.33 \\
4. Making connections between letters correctly & .86 & 4.17 \\
5. Writing letters' extensions correctly, & .79 & 4.32 \\
6. Writing on the line, & .69 & 4.53 \\
7. Leaving appropriate place between words, & .76 & 4.37 \\
8. Writing cleanly (without any sign of eraser or scribble) & .86 & 4.24 \\
9. Writing in line with page format, & .93 & 4.00 \\
10. Writing letters with dots and lines $(\breve{g}, \mathrm{i}, \mathrm{t}$ etc.) correctly. & .82 & 3.64 \\
Total & $\mathbf{. 6 2}$ & $\mathbf{4 . 0 7}$ \\
\hline
\end{tabular}

As it is seen in Table 1, the average score for $3^{\text {rd }}$ grade students' success level in legible handwriting is $\bar{X}=4.07$. According to Table 1, students' level of legible handwriting is good.

Their level of skill for "writing without disrupting the slope" is moderate ( $\bar{X}=3.33)$. And their skill level for writing on the line, extending the letters correctly, leaving appropriate space between words and writing cleanly, is very high, with averages between the range of $\bar{X}=4.32-4.53$. On the other hand, skills of shaping letters correctly, writing letters in appropriate sizes, making connections appropriately and writing letters with dots and lines correctly are good, changing within the range of $\bar{X}=3.97-4.17$.

Data related to 3rd grade students' success level in legible written expression is provided in Table 2.

Table 2. Data related to written expression skills.

\begin{tabular}{lrc}
\hline Skills & s.d. & $\bar{X}$ \\
\hline 1. Writing without any defects of expression in the sentence. & .70 & 2.98 \\
2. Maintaining integrity of expression between the sentences. & 1.02 & 3.24 \\
3. Maintaining story line (plot) in writing & 1.03 & 3.41 \\
4. Writing an appropriate introduction. & 1.00 & 3.68 \\
5. Writing an appropriate title. & 1.00 & 3.84 \\
6. Writing sentences with appropriate verb tenses. & .85 & 3.34 \\
7. Writing without repetition of same meaning. & 0.95 & 3.46 \\
8. Writing without going off the topic. & 1.18 & 3.27 \\
9. Writing without going off the main idea. & 1.03 & 3.01 \\
10. Writing an appropriate conclusion & 1.10 & 3.10 \\
Total & $\mathbf{. 8 3}$ & $\mathbf{3 . 3 3}$ \\
\hline
\end{tabular}

It is observed that the average score for written expression skills is $\bar{X}=3.33$. According to Table 1, students' success level for written expression skills is moderate. 
Level of skills for "Maintaining a story line in writing, writing an appropriate introduction, and writing without repetition of the same meaning is good, with scores ranging between $\bar{X}=3.41-3.84$.

Lowest level of success is observed for the skill of writing without expression defects: $\bar{X}=2.98$. Success levels for skills of "maintaining integrity of expression between sentences, writing with appropriate verb tenses, without going off the topic and off the main idea and writing an appropriate conclusion." are moderate with scores between the ranges of $\bar{X}=3.01-3.34$.

The relationship between the success levels of legible handwriting and that of written expression for third grade students is given in table 3 .

Table 3. Data related to legibility and success level for written expression.

\begin{tabular}{lcccccr}
\hline & $\mathbf{N}$ & $\bar{X}$ & s.d & r & p \\
\hline Legibility & 110 & 4.07 & .62 & .62 & .000 \\
Written Expression & 110 & 3.33 & .83 & & \\
\hline
\end{tabular}

$\mathrm{p} \leq .001$

The existence of a meaningful relationship between legible handwriting and students' success levels in written expression is tested with Pearson Product Movement Correlation Coefficient. As it is seen in Table 3, r =.62. It can be stated that there is moderate relationship between student's success levels in legible handwriting and their success levels for written expression.

\section{Discussion and Conclusion}

The findings of this study, which analyzes primary school third grade students' skills for handwriting and written expression, reveal that students' skill level in legible handwriting is good. When studies featuring the opinions of students and teachers involved in cursive slant handwriting since its initiation in Turkey are reviewed, it can be stated that there are different conclusions.

For example, Ateş, Çetinkaya and Yıldrım (2014) concluded that classroom teachers believe that students' difficulties in writing, to a large extend, stems from cursive slant handwriting. In his study, Duran (2011) reached to the conclusion that a certain percentage of the teachers involved in his research $(n=36,16 \%)$ think that not all spellings of cursive slant letters used in teaching reading \& writing are appropriate and it is necessary to start teaching reading and writing with manuscript. It is found out that $50.8 \%$ of the teachers prefer cursive slant handwriting while remaining 49.2 is in favor of manuscript. Kirmızı and Kasap (2013) stated that teachers found using manuscript much easier both during the preparatory stage for reading \& writing and during teaching of writing itself and they claimed that students wrote more legible and stylish with manuscript. It was found out that the majority of the teacher's preferred using manuscript as they found it difficult to teach reading and writing with cursive slant letters. In their research on 6th grade students, Akkaya and Kara (2012) determined that $39.9 \%$ of the students did not use cursive slant letters in writing; they didn't make use of cursive slant handwriting because they had negative attitude towards it, manuscript was widely used, cursive slant handwriting was not legible and their teachers had influence over them. However, Şahin (2012) found out that teachers generally had not faced much problem in teaching cursive slant handwriting. Hammerschmidt and Sudsawad (2004) indicated that while evaluating students' handwriting, teachers judged whether their writing was legible and fast by comparing them with their peers in addition to general criteria. Teachers took into account the willingness of students in participating in writing activities in addition to legibility.

It can be stated that, similar to studies reviewing students' and teachers' opinions, studies analyzing the success levels of students in handwriting have different (contradicting) conclusions as well. For example Bay (2010) concludes that developments of primary school first grade students' writing skills are generally at normal levels and all students except students under inclusive program are complaint with writing rules. In addition to that, students who commit writing errors mostly (40\%) do so in cursive slant writing. Bayat and Çelenk (2015) also has found that first grade students' writing skills are sufficient but the lowest level of success is observed in stylish and legible writing. Coşkun and Coşkun (2012) established that handwriting skills of classroom teachers' and Turkish Language teachers' were moderate, and 3rd and 8th grade students had bad handwriting skills while 5th and 6th graders' skills were at moderate level. Bayat (2016a), in his study on 8th grade students who first learned reading and writing with cursive slant letters, concluded that students, when they were set free, had a very low tendency to prefer cursive slant writing (17\%) and their level of success in legible handwriting were at moderate levels, their success level in fast writing was good, and there was no meaningful difference in their levels of success in legible and fast writing according to style of writing that was chosen.

Given these studies made in literature, it is obvious that there are certain problems faced in teaching cursive slant handwriting in Turkey. But, when studies analyzing the success levels of students are taken into account, it is noticed that different results have been obtained in different classes. In this context, it is difficult to make a generalization about 
whether teaching of cursive slant handwriting in Turkey has been successful or not. Indeed, in this study, 3rg grade students' level of success in legible handwriting is found moderate. However, it is thought-provoking that in researches made in Turkey (Bayat, 2016b; Duran \& Bitir, 2015; Yıldız' et al., 2016), it is noted that as students attend to a higher class, they tend to prefer writing manuscript letters despite the fact that they don't get a formal basic education on manuscript whereas one of the reasons for transition to cursive slant handwriting has been the argument that students enjoy this style of writing (MEB 2006). The fact that students do not prefer cursive slant hand writing could be interpreted as an indication of success/failure. Because, in addition to students' success in cursive slant writing in schools, students' preference when they are left free to choose in the school or in their daily life is also an important factor that should be taken into account. Moreover, some studies (Bayat; 2016a; Graham et, al., 1998; Morin, et al., 2012) conclude that style of writing (Cursive, Manuscript, Mix) does not make any meaningful difference in terms of legibility or speed of writing. Under these circumstances, it can be said that both styles of writing should be taught in the schools and the decision to choose one of them should be left to the students rather than insisting on teaching a single style of writing in the education system.

In this study, third grade students' the level of success in written expression is also analyzed. It is found out that most common errors that students commit are making expression defects (incoherence in writing) and going off the main idea. In total, students' level of success in written expression is found to be moderate. A process based approach to writing have been adopted in this study and students have been asked to write a story based on key words given to them. In studies (Dağtaş, 2012; Bayat, 2016b; Bayat, 2014) where a process based approach to writing is adopted, it is observed that students' written expression and creative writing skills are improved. For this reason, it's possible to say that, in order to improve students' written expression skills, it is necessary to allocate enough time to activities in which they can write on subjects that are interesting for them (Akkaya, 2014; Smith, 2013) and in which a process based approach to reading is adopted (Badger \& White, 2000; Bayat, 2014; Graham et al., 2013).

Finally, in this study, it is also determined that there is a moderate level of relationship between 3rd grade students level of success in legible handwriting and their success level for written expression. While evaluating skills of written expression, punctuation errors and misspellings have been ignored and the focus has been on the fluent expression of thoughts and feeling by students, that is to say, on the content. Skills to write legibly are evaluated separately. In literature (Berninger, 1999; Santangelo \& Graham, 2015; Olive \& Kellog, 2002), it is claimed that success in handwriting affects success in written expression. This study has found out that students' scores for legible handwriting are good while their scores for written expression is moderate. Given that relationship between success in handwriting and success in written expression is also moderate, it is possible to think that cursive slant handwriting does not have a very profound effect over written expression skills. However, in order to have a clear idea in this subject, it is necessary to make studies with much broader bases. Because, there are many other factors affecting students level of success in written expression, such as development of language, socio-cultural conditions, vocabulary, attitudes towards writing etc. New experimental studies may be carried out where all these variables are kept under control, by studying levels of success in legibility, speed and written expression in different writing styles (cursive, manuscript and mix).

\section{References}

Akkaya, A., \& Kara, Ö. T. (2012). 6. sınıf öğrencilerinin bitişik eğik yazıda yaşadıkları sorunların nedenleri üzerine görüşleri. Erzincan Üniversitesi Eğitim Fakültesi Dergisi, 14(2), 313-336.

Akkaya, N. (2014). Elementary teachers' views on the creative writing process: An evaluation. Educational Sciences: Theory \& Practice, 14(4), 1499-1504.

Armstrong, K. (2014). Cursive handwriting in an internet age. World Academy of Science, Engineering and Technology, International Journal of Social, Behavioral, Educational, Economic, Business and Industrial Engineering, 8(11), 3472-3478.

Ates, S., Cetinkaya, C., \& Yildirim, K. (2014). Elementary school classroom teachers' views on writing difficulties. International Online Journal of Educational Sciences, 6(2). http://dx.doi.org/10.15345/iojes.2014.02.018

Badger, R., \& White, G. (2000). A process genre approach to teaching writing. ELT Journal, 54(2), 153-160. http://dx.doi.org/10.1093/elt/54.2.153

Başaran, M., \& Karatay, H. (2005). Eğik el yazısı öğretimi. Millî Eğitim Dergisi, 33(168), 27-34.

Bay, Y. (2010) Ses temelli cümle yöntemiyle ilk okuma-yazma öğretiminin değerlendirilmesi. Ahi Evran Üniversitesi Eğitim Fakültesi Dergisi, 1(1), 257-277.

Bayat, N. (2014). The effect of the process writing approach on writing success and anxiety. Educational Sciences: Theory \& Practice, 14(3), 1133-1141 
Bayat, S. (2016a). Sekizinci sınıf öğrencilerinin el yazısı yazma becerilerinin değerlendirilmesi/Evaluation of eighth graders' handwriting skills. Kastamonu Ë̆itim Dergisi, 24(3), 955-972.

Bayat, S. (2016b). The effectiveness of the creative writing instruction program based on speaking activities (CWIPSA). International Electronic Journal of Elementary Education, 8(4), 617-628.

Bayat, S., \& Çelenk, S. (2015). İlköğretim birinci sınıf öğrencilerinin okuma yazma becerileri başarı düzeylerinin belirlenmesi./Elementary first year students' success on reading-writing) Illkögretim Online, 14(1), 13-28.

Bayat, S., \& Çoşkun, M. (2016). The Examination of Second Grade Students' Writing Success at Primary School Accordıng to Their Classroom Type. Sakarya Üniversitesi Eğitim Fakültesi Dergisi, 31, 74-87

Berninger, V. W. (1999). Coordinating transcription and text generation in working memory during composing: Automatic and constructive processes. Learning Disability Quarterly, 22(2), 99-112. http://dx.doi.org/10.2307/1511269

Blazer, C. (2010). Should cursive handwriting still be taught in schools? (Vol. 0916). Retrieved from: http://files.eric.ed.gov.zeus.tarleton.edu:82/fulltext/ED544702.pdf

Blumendfeld, S. (1997). Homeschooling: a parent's guide to teaching children. Boise, Idaho: The Paradigm Company.

Bo, J., Barta, J., Ferencak, H., Comstock, S., Riley, V., \& Krueger, J. (2014). Developmental characteristics in cursive and printed letter-writing for school-age children. Journal of Motor Learning and Development, 2, 1-8. http://dx.doi.org/10.1123/jmld.2012-0001

Burns, P. C. (1968). Improving handwriting instruction in elementary schools. Minneapolis, MN: Burges Publishing.

Coşkun, E., \& Coşkun, H. (2012). İlköğretim öğrencileri ile sınıf ve Türkçe öğretmenlerinin bitişik eğik yazı başarı düzeylerinin değerlendirilmesi. Gazi Üniversitesi Gazi Eğitim Fakültesi Dergisi, 32(3), 761-776

Dağtaş, A. (2012). Kelime ve kavram havuzundan seçerek yazma tekniğinin öğrencilerin yazma becerilerine etkileri /Pool by selecting the word and concept writing technique to the effects of students' writng skills. Turkish Studies, - International Periodical for the Languages, Literature and History of Turkish or Turkic, 7(3), 845-869.

Duran, E. (2011). Bitişik eğik yazı harflerinin yazım şekillerine ilişkin öğretmen görüşleri. Ondokuz Mayıs Üniversitesi Eğitim Fakültesi Dergisi, 30(2), 55-69.

Duran, E., \& Bitir, T. (2015). Lise öğrencilerinin bitişik eğik yazıyı kullanım durumları/Cursıve handwrıtıng usage for high school students. The Journal of Academic Social Science Studies, 2(38), 49-59. http://dx.doi.org/10.9761/JASSS3047

Duvall, B. (1985). Evaluating the difficulty of four handwriting styles used for instruction. Spectrum, 3(3), 13-20.

Farris, P. J. (1997). Language arts process, product, and assessment (2nd edition). Madison, WI: Brown \& Benchmark.

Giedd, J. N., Snell, J. W., Lange, N., Rajapakse, J. C., Casey, B. J., Kozuch, P. L., ... Judith, L. R. (1996). Quantitative magnetic resonance imaging of human brain development: Ages 4-18. Cerebral Cortex, 6, 551-560. http://dx.doi.org/10.1093/cercor/6.4.551

Giedd, J., Castellanos, X., Blumenthal, O., Molloy, E., Clasen, L., Jeffries, N. (2001). Cerebellum: Unique developmental morphometric characteristics during childhood and adolescence. NeuroImage, 13(6), 1304. http://dx.doi.org/10.1016/S1053-8119(01)92618-7

Göçer, A. (2010). Türkçe öğretiminde yazma eğitimi/ writing education in Turkish teaching. Uluslararası Sosyal Araştırmalar Dergisi/ The Journal of International Social Research, 3(12), 178-195.

Graham, S. (1992). Issues in handwriting instruction. Focus Except. Child, 25, 1-14.

Graham, S., Gillespie, A., \& McKeown, D. (2013). Writing: Importance, development, and instruction. Reading and Writing, 26(1), 1-15. http://dx.doi.org/10.1007/s11145-012-9395-2

Graham, S., Hebert, M., Sandbank, M. P., \& Harris, K. R. (2016). Assessing the Writing Achievement of Young Struggling Writers Application of Generalizability Theory. Learning Disability Quarterly, 39(2), 72-82. http://dx.doi.org/10.1177/0731948714555019

Graham, S., Weintraub, N., \& Berninger, V. W. (1998). The relationship between handwriting style and speed and legibility. The Journal of Educational Research, 91(5), 290-297. http://dx.doi.org/10.1080/00220679809597556

Güneş, F. (2007) Bitişik eğik yazının yararları. Eğitim ve Denetim, Tüm Eğitimciler ve Eğitim Müfettişleri Sendikası Yayın Organı (TEM-SEN), 17(5), 9-15

Hammerschmidt, S. L., \& Sudsawad, P. (2004). Teachers' survey on problems with handwriting: Referral, evaluation, 
and outcomes. American Journal of Occupational Therapy, 58(2), 185-192. http://dx.doi.org/10.5014/ajot.58.2.185

Jackson, A. D. (1970). A comparison of speed and legibility of manuscript and cursive handwriting of intermediate grade pupils. Unpublished doctoral dissertation, University of Arizona, Tucson.

Kaminsky, S., \& Powers, R. (1981). Remediation of handwriting difficulties, a practical approach. Acad. Ther., 17, 19-25. http://dx.doi.org/10.1177/105345128101700103

Karasar, N. (2005). Bilimsel Araştırma Yöntemi: Kavramlar, İlkeler ve Teknikler. Ankara: Nobel Yayıncılık

Karlsdottir, R. (1996). Print-script as initial handwriting style: I. Effects on the development of handwriting. Scandinavian Journal of Educational Research, 40(2), 161-174. http://dx.doi.org/10.1080/0031383960400204

Kırmızı, F., \& Kasap, D. (2013). İlkokuma yazma öğretimi sürecinde bitişik eğik yazı ve dik temel harflerle yapılan eğitimin öğretmen görüşlerine göre karşılaştırılması. (A comparison of cursive italıc writing and basic vertical letters while teaching basal reading and writing based on teachers' views)Turkish Studies-International Periodical for the Languages, Literature and History of Turkish or Turkic, 8(8), 1167-1186.

Kiuhara, S. A., Graham, S., \& Hawken, L. S. (2009). Teaching writing to high school students: A national survey. Journal of Educational Psychology, 101(1), 136-160. http://dx.doi.org/10.1037/a0013097

Klemm, W. (2013). What learning cursive does for your brain? In Psychology today March, 2013, Retrieved from: http://www.psychologytoday.com/ blog/memory-medic/201303/what-learning-cursive-does-your-brain

Koenke, K. (1986). Handwriting Instruction: What Do We Know? The Reading Teacher, 40(2), 214-216.

Kuhl, D., \& Dewitz, P. (1994). The effect of handwriting style on alphabet recognition. New Orleans: Paper presented at the American Educational Research Association Meeting.

MEB (2006). Türkçe Öğretim Programı (1-5. Sinıflar). Retrieved from http://ttkb.meb.gov.tr/www/ogretim-programlari/icerik/72

Morin, M. F., Lavoie, N., \& Montésinos-Gelet, I. (2012). The effects of manuscript, cursive or manuscript/cursive styles on writing development in Grade 2. Language and literacy, 14(1), 110. http://dx.doi.org/10.20360/G21S3V

Mosse, H. (1982). You can prevent or correct learning disorders. Beaverton, Or: Riggs İnstitute.

New American Cursive Penmanship Program. (2009). Teaching Tips and Other Helpful Items. Retrieved from http://www.newamericancursive.com/faq.

Olive, T., \& Kellog, R. T. (2002). Concurrent activation of high and low level production processes in written composition. Memory and Cognition, 30, 594-600. http://dx.doi.org/10.3758/BF03194960

Otto, W., \& Rarick, G. L. (1969). Effect of time of transition from manuscript to cursive writing upon subsequent performance in handwriting, spelling and reading. Journal of Educational Research, 62(5), 211-216. http://dx.doi.org/10.1080/00220671.1969.10883819

Owens, L. (2009). Fox News Guests Debate To Keep or Kill Cursive: Some Feel Handwriting Outdated With Electronic Communication Tools. Retrieved from http://americanaffairs.suite101.com/article.cfm/fox_news_debate_to_keep_or_curtail_cursive.

Puranik, C. S., Al Otaiba, S., Sidler, J. S., \& Greulich, L. (2014). Exploring the amount and type of writing instruction during language arts instruction in kindergarten classrooms. Reading and Writing, 27(2), 213-236. http://dx.doi.org/10.1007/s11145-013-9441-8

Rosenblum, S., Weiss, P. L., \& Parush, S. (2003). Product and process evaluation of handwriting difficulties. Educational Psychology Review, 15(1), 41-81. http://dx.doi.org/10.1023/A:1021371425220

Rubin, N., \& Henderson, S. E. (1982). Two sides of the same coin: variations in teaching methods and failure to learn to write. British Journal of Special Education, 9(4), 17-24. http://dx.doi.org/10.1111/j.1467-8578.1982.tb00576.x

Şahin, A. (2012). Problems with the teaching of cursive handwriting. Education and Science, 37(165), 168-179.

Santangelo, T., \& Graham, S. (2015). A comprehensive meta-analysis of handwriting instruction. Educational Psychology Review, 1-41.

Schwellnus, H., Cameron, D., \& Carnahan, H. (2012). Which to Choose: Manuscript or Cursive Handwriting? A Review of the Literature. Journal of Occupational Therapy, Schools, \& Early Intervention, 5(3-4), 248-258. http://dx.doi.org/10.1080/19411243.2012.744651

Sharp, L. A., \& Titus, S. (2016). Is Handwriting Instruction Outdated? A Replication Study of Teachers' Perspectives. The Reading Professor, 38(1), 27-36. 
Smith, F. (2013). Writing and the writer. New York: Routledge. https://books.google.com.tr/books?

Spencer, R. M. C., Zelaznik, H. N., Diedrichsen, J., \& Ivry, R. B. (2003). Disrupted timing of discontinuous but not continuous movements by cerebellar lesions. Science, 300, 1437-1439. http://dx.doi.org/10.1126/science.1083661

Sudsawad, P., Trombly, C. A., Henderson, A., \& Tickle-Degnen, L. (2001). The relationship between the Evaluation Tool of Children'sHandwriting and teachers' perceptions of handwriting legibility. American Journal of Occupational Therapy, 55, 518-523. http://dx.doi.org/10.5014/ajot.55.5.518

Tavşancıl, E., \& Aslan. A. E. (2001). Sözel, yazılı ve diğer materyaller için içerik analizi ve uygulama örnekleri. İstanbul: Epsilon Yayınevi.

Tinker, M. A. (1955). Prolonged reading tasks in visual research. Journal of Applied Psychology, 39, 444-445. http://dx.doi.org/10.1037/h0041553

Tosunoğlu, M. (2010). Farklı yazı stillerinin okuduğunu anlama sürecine etkisi. Türklük Bilimi Araştırmaları, 27(27), 679-690.

Trap-Porter, J., Cooper, J. O., Hill, D. S., \& Swisher, K. (1984). D’Nealian and Zaner-Bloser manuscript alphabets and initial transition to cursive handwriting. Journal of Educational Methods, 77(6), 343-345.

http://dx.doi.org/10.1080/00220671.1984.10885553

Troyer, N. (2005). Lost Art of Penmanship: Cursive Writing a Casualty of Technological Age. The Washington Times, January 18.

Yıldırım, A., \& Şimşek, H. (2005). Sosyal bilimlerde nitel araştırma yöntemleri. Ankara: Seçkin Yayıncılık.

Yıldız, M., Ataş, M., Yekeler, A. D., \& Aktaş, N. (2016). How did they learn the manuscript writing? How do they write?" Turkish Studies -International Periodical for the Languages, Literature and History of Turkish or Turkic, $11(3), 2461-2480$.

Ziviani, J., \& Watson-Will, A. (1998). Writing speed and legibility of 7-14 - year - old school students using modern cursive script. Australian Occupational Therapy Journal, 45(2), 59-64. http://dx.doi.org/10.1111/j.1440-1630.1998.tb00783.x 